\title{
İlköğretim İkinci Kademede Okutulan Derslerin Kültürel Mirası Korumada Amaçlarına Uygunluğunun Değerlendirilmesi
}

\author{
(1) Yrd. Doç. Dr. Aydın Zor \\ (2) Arş. Gör. Fatih Karip \\ Öz
}

Bu çalışmada ilköğretim ikinci kademe derslerinin müfredat programları, ders kazanımları ve 2011 yılında Milli Eğitim Bakanlığı tarafından hazırlanarak okullara dağıtılan ilköğretim ders kitaplarında yer alan üniteler, kültürel miras öğeleri dikkate alınarak incelenmiştir. Araştırma verileri nitel araştırma yöntemlerinden doküman incelemesi yoluyla toplanmışıı. ilköğretim ikinci kademede yer alan tüm kazanımlar tek tek incelenmiş, elde edilen bulgular tablolar halinde sunularak, incelenen ünitelerden doğrudan alıntılar yapılmış ve yorumlanmıştır.

Anahtar Kelimeler: Kültürel Miras, Koruma, Ilköğretim ikinci Kademe, Kazanımlar, Müfredat Program

\section{ASSESSMENT OF SECONDARY SCHOOL COURSES WHICH AIM OF SUITABILITY SAVING CULTURAL HERITAGE}

\begin{abstract}
On this project, secondary school curriculums, acquisitions and the units in primary school coursebooks which are prepared and dealt to schools in 2011 by Turkish Ministry of Education have been examined by taking consideration the cultural heritage items. The datas of this project were collected with examining file which is a kind of qualitative research. The whole gains in the secondary school were examined one by one. By finding datas were presented in charts, it was quatated directly from the examined units and commented.
\end{abstract}

Keywords: Cultural Heritage, Protection, Secondary School, Acquisitions, Curriculums

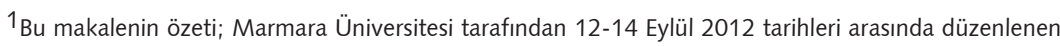
21. Ulusal Eğitim Bilimleri Kongresinde yayımlanmışıır.

(1) Ağrı İbrahim Çeçen Üniversitesi Eğitim Fakültesi Güzel Sanatlar Eğitimi Bölümü, AĞRI e-posta: azor@agri.edu.tr

(2) Ağrı İbrahim Çeçen Üniversitesi Eğitim Fakültesi Güzel Sanatlar Eğitimi Bölümü, AĞRI

e-posta: fkarip@agri.edu.tr 


\section{Giriş}

Çevre sorunları, salt yaşadığımız çevrenin fiziksel kirlemesini değil, doğal ve tarihi çevrenin bozulması sürecini de içermektedir. Bu bağlamda tarihsel ve kültürel değerlerin oluşturduğu bu mekânların olumsuz yönde değişmesi, bozulması ve yok olmasını önlemek büyük önem arz etmektedir.

Kültürel çevremiz bilinçli yada istemeden birçok tahribatla karşı karşıya kalmaktadır. Kültür varlıklarını günışığına çıkarmayı hedefleyen arkeolojik kazılar tarihsel kalıntıların bilimsel metotlarla ortaya çıkarılması ve yaygınlaştııımasını hedefler. Ancak kültür varlıklarının araştıııması, tarihsel kalıntıların geri dönüşü olmayan bir şekilde tahribatı tehlikesini de beraberinde getirdiğinden, korumacılık ayrıcalıklı bir anlam kazanmaktadır (Hueber, 1991: 38).

Kültür varlıklarının tahrip edilmesindeki en önemli hususlardan biri kuşkusuz sanayileşmedir. Özellikle gelişmekte olan ülkelerde sanayileşme ile gerek şehirleşme bağlamında gerekse tek nesne olarak benzer birçok tahribatın yaşandığı görülmektedir (Göğebakan, 2009: 30). Modernleşme adına yapılan yapılaşma eylemleri hemen her yerleşmede ya da kırsal alanlarda kültür ve doğa varlıklarının çoğunun değişmesine, bozulmasına ya da yok olmasına neden olmaktadır (Asatekin, 2004: 49).

Kültürel mirasımıza yönelik yapılan tahribatların en üzücüsü ise tarihi çevre gezilerinde ziyaretçilerin tarihi yapılar üzerine yaptığı yazı ve kazımalarla oluşan tahribattır. Bir taraftan kültür varlıklarını tanımak, kültürlenmek isteyen ziyaretçinin diğer taraftan bu değerlere zarar vermesi korumacılığın fiziksel değil de bilişsel bir olay olduğunu göstermektedir.

Ülkemiz binlerce yıllık bir süreç içinde yer almış uygarlıkların birikimi olan kültürel ve doğal değerleri barındırmaktadır. Bu değerlerin bir bütün olarak algılanması, değerlendirilmesi ve korunması özgün kimliği ile Türkiye'nin var oluş mücadelesini oluşturmaktadır. Bu değerlerin yok olması kültürel sürekliliğin kesintiye uğraması, geleceğe temel olan birikiminin kaybedilmesi demektir (Çubuk, 1998: 1).

21. yüzyılda ülkelerin doğal ve tarihi çevrelerini koruma becerisi ve başarısı sadece doğal ve kültürel zenginlik olarak değil, aynı zamanda siyasal bir güç ve prestij kaynağı olarak öne çıkmaktadır. Bu kültür değerlerinin yansıma düzlemleri de kuşkusuz kentler olacaktır. Sahip olduğu kültürel ve doğal varlıklarının değeri ve kapsamı düşünülürse, Türkiye'nin tarihi ve doğal çevreyi koruma konusunda sağlayabileceği başarı uygarlık yarışındaki en önemli ve değerli gücü olacaktır. (Tankut, 1991: 9)

Kültürel mirasın korunmasında yasal olarak merkezi yönetimlere ve 
yerel yönetimlere sorumluluklar verilmiştir. Sivil toplum kuruluşları ve halk da bu sorumluluğu üstlenmektedir. (Yılmaz ve Üçler, 2004: 43). Bununla birlikte gerekli teknik/kurumsal donatıya sahip mimarların ya da kısıtlı sayıdaki diğer uzmanların varlığı ülkemizdeki değerlerin korunması için yeterli değildir. Önemli olan bu ülkede yaşayan her bireyin, ait olduğu toplumun kültürel geçmişini benimsemesi, bu topraklarda var olan ve çağdaş benliğimizin temelini oluşturan her türlü kültür ve doğa varlıklarının öneminin ayırtına varmaları, bunlara sahip olmaktan gurur duymalarıdır (Asatekin, 2004: 18).

Çağdaş toplumlar sahip oldukları kültürel zenginlikleri koruyarak gelecek kuşaklara taşımak için özel bir çaba sarf eder. Tarihi çevreleriyle uyum içerisinde yaşama becerisine sahiptirler. Çünkü gelecek nesilleri ayakta tutacak en temel güç geçmişten alınan güçtür. Geçmişe dair bir toplumun en önemli varlıkları ise tarihi çevreyi oluşturan evler, sokaklar, anıtlar, dini ve sosyal yapılar, maddi ve manevi bütün kültürel değerleridir.

\section{Koruma Bilincinin Oluşmasında Eğitimin Önemi}

Türkiye Cumhuriyeti Anayasası 42. maddesi ile 'Eğitim ve Öğrenim Hakkı ve Ödevini' Kimse, eğitim ve öğrenim hakkından yoksun bırakılamaz maddesi ile belirtmiştir². Bu ana çerçeve doğrultusunda Milli Eğitim Bakanlığı, Milli Eğitim Temel Kanunu ile Türk Milli Eğitiminin genel amaçlarını belirlemiştir.

Türk eğitim sistemi, bu genel amaçları gerçekleştirecek şekilde düzenlenir ve çeşitli derece ve türdeki eğitim kurumlarının özel amaçları, bu genel amaçlara uygun olarak gerçekleştirilir. Illköğretim okullarında okutulan dersler Milli Eğitim Bakanlığı tarafından belirlenir ve bu derslerin temel kaynağı alan ders kitapları Talim Terbiye Kurulu tarafından Türk Milli Eğitiminin genel amaçlarına uygun olarak düzenlenir.

Türk eğitim sisteminin genel amaçları arasında bireylerin milli ve manevi değerleri benimsemeleri ve koruyup geliştirmeleri yer almaktadır. Kültür varlıklarının niceliği ve niteliği bakımından çok önemli bir konuma sahip olan ülkemiz açısından bu genel amacı gerçekleştirmek oldukça önemlidir.

Kültürel mirasa sahip olma açısından baktığımızda, potansiyelimizle koruma çabalarımızın gereği kadar örtüşmediğini, bir bilinç yaratma konusunda eksiklikler bulunduğunu söyleyebiliriz. Koruma konusunda temel yaklaşımımızın bütün toplumsal kesimleri kapsayacak şekilde henüz netleşmediğini söylemek mümkündür (Bilgili, 2010: 328).

Ülkemiz kültürel mirası koruma politikaları konusunda ulusal ve uluslararası platformda önemli bir mesafe kat etmiştir. Ancak koruma bilincinin toplumsal tabana yayılarak bir 'koruma kültürü' oluşturulma

2 www.mevzuat.meb.gov.tr 
noktasında önemli eksikliklerinin olduğu görülmektedir. Bu nedenle tarihsel çevrenin sağlıkı bir şekilde korunması ve değerlendirilmesi için bu alanda uygulanan politika ve çalışmaların ekonomik temelden uzaklaşarak; sosyal, kültürel, eğitimsel boyutlarıyla ele alınmasına gereksinim duyulmaktadır (Altınörs, 2010: 30).

Toplumu oluşturan bütün kesimlerin koruma konusunda bilinçlenmesi paralelinde ülke koruma politikalarını etkilemeye kadar gidebilecek bir bakışı tanımlayan toplumsal boyut, bu anlamda bir güç oluşturmaktadır. Toplumun korumaya bakışı ne kadar bilinçli olursa, doğru uygulamalar da o kadar artacaktır. Çünkü yanlış ve kötü uygulamalar karşısında duracak bir toplum baskısı, uygulamacıları doğrudan etkileyecektir. Ancak ülkemizde böyle bir bilinç olmadığı gibi, planlama sistemimiz de katılımcı değildir (Özden, 2005: 33).

Koruma konusunda örgün ve yaygın eğitimin yetersizliği, kültür varlıklarımızın korunamamasında önemli bir rol oynamaktadır. Özellikle, ilköğretim ve ortaöğretimde korumanın neden gerektiğinin, kültür sürekliliğinin ülke bireylerinin yurtseverliliğini, dolayısıyla yurtlarına bağlılığını neden arttırdığının öğrencilere anlatılması gerekmektedir. Bireyin, yaşadığı toprakların somut veya soyut kültürüne sahip çıkmasının, o kültürü gelecek nesillere doğru bir biçimde aktarmasının, yaşama kültürümüzün vazgeçilmez öğesi olduğunu unutmamalıyız (Tapan, 2010: 52).

Ülkemizde kültür ve doğa varlıklarının korunması konusunda kişilerin bilgilendirilmesi, üniversite aşamasına hatta yüksek lisans öğretimine bırakılmaktadır. Bir toplumu oluşturan bireylerin temel kişilik niteliklerinin belirlenip kesinleşmesinden sonra bir 'ek' olarak kültürel geçmişin öneminin ayırtına varılması için bilgi verilmesi, bu bilginin kimliğin ayrılmaz bir parçası haline gelmesi için oldukça geç bir zamandır (Asatekin, 2005: 51). Bu nedenle çocuklarda ilköğretim döneminde hatta okul öncesi dönemde uygun materyallerle ve etkinliklerle tarihi çevre bilinci uyandırılmalı, 'koruma bilinci' oluşturulmalıdır.

$\mathrm{Bu}$ çalışmanın amacı ilköğretimde okutulan derslerin müfredat programlarında yer alan genel amaçlarını inceleyerek, bu amaçlar doğrultusunda hazırlanmış amaç ve kazanımların ilköğretim öğrencilerinde kültürel mirasın korunması bilincine ne derece hizmet ettiğini ortaya koymaktır. Ayrıca ilköğretim ikinci kademede okutulan zorunlu ve seçmeli dersler, ders kitaplarında yer alan üniteler, koruma bilinci bağlamında incelenerek tablolar halinde sunulmuştur.

İlköğretim ikinci kademede okutulan derslerden kültürel mirası koruma bilinci oluşturabilecek, tarihi mekânlara karşı olumlu bakış açısı kazandırabilecek dersler Türkçe, Sosyal Bilgiler, Din Kültürü ve Ahlak Bilgisi, Görsel Sanatlar, Halk Kültürü, Sanat Etkinlikleri dersleridir. 


\section{Türkçe Dersi}

İlköğretim $(6,7,8)$ Türkçe müfredat programı incelendiğinde, programın genel amaçlarının 9. maddesinde geçen 'Türk ve dünya kültür ve sanatına ait eserler aracılığıyla millî ve evrensel değerleri tanımaları' amacı yer almasına karşın, dersin kazanımları ve ara disiplin alan kazanımları arasında kültürel mirası koruma bilinci oluşturacak herhangi bir kazanım bulunmamaktadır. (MEB, 2006b: 4)

Ancak Illköğretim Türkçe Dersi üniteleri ve bu üniteler içerisinde yer alan konulara bakılıp, okuma parçaları göz önünde bulundurulduğunda kültürel değerlere karşı olumlu bakış açısı kazandırabilecek ünitelerin yer aldığı görülmektedir (Tablo 1).

\begin{tabular}{|l|l|l|l|}
\hline \multicolumn{1}{|c|}{ Üniteler } & \multicolumn{1}{c|}{ 6. Sunff } & \multicolumn{1}{c|}{ 7. Sunif } & \multicolumn{1}{c|}{ 8. Sunıf } \\
\hline $\mathbf{1}$ & Sevgi & Hak ve Özgürlük & Duygular \\
\hline $\mathbf{2}$ & Atatürk & Atatürk & Atatürk \\
\hline $\mathbf{3}$ & Kişisel Gelişim & Doğa ve Evren & Doğa ve Evren \\
\hline $\mathbf{4}$ & Güzel Sanatlar & Duygular ve Harfler & Toplum Hayat1 \\
\hline $\mathbf{5}$ & Duygular & Alişkanlıklar & İleti̧̧im \\
\hline $\mathbf{6}$ & Doğa ve Evren & Milli Kültür & Zaman ve Mekân \\
\hline
\end{tabular}

Tablo1: Ilköğretim Ikinci Kademe Türkçe Dersi Üniteleri

\section{Sosyal Bilgiler}

İlköğretim Sosyal Bilgiler Dersi incelendiğinde, programın genel amaçlarının 5. maddesinde 'Türk kültürünü ve tarihini oluşturan temel öğe ve süreçleri kavrayarak, milli bilincin oluşmasını sağlayan kültürel mirasın korunması ve geliştirilmesi gerektiğini kabul eder' amacı yer alır³. Bu genel amaç doğrultusunda tarihi mekânlara ve kültürel mirasa olumlu bakış açısı kazandırabilecek kazanımlar, 'Kültür ve Miras' öğrenme alanında yer almaktadır.

\section{Sınıf Kültür ve Miras Öğrenme Alanı Ipek Yolunda Türkler Ünitesi Kazanımları}

1. Destan, yazıt ve diğer belgelerden yararlanarak, Orta Asya ilk Türk devletlerinin siyasal, ekonomik ve kültürel özelliklerine ilişkin çıkarımlarda bulunur.

2. Orta Asya ilk Türk devletlerinin kültürel özellikleriyle yaşadıkları yerlerin coğrafî özelliklerini ilişkilendirir.

3. Ipek Yolu'nun toplumlar arası siyasal, kültürel ve ekonomik ilişkilerdeki rolünü fark eder.

4. Türklerin İslamiyet'i kabulleri ile birlikte siyasî, sosyal ve kültürel alanlarda meydana gelen değişimleri fark eder.

\footnotetext{
$3_{\text {www.ttkb.meb.gov.tr }}$
} 
5. Dönemin devlet adamları ve Türk büyüklerinin hayatından yararlanarak ilk Türk - İslam devletlerinin siyasal, sosyal ve kültürel özelliklerine ilişkin çıkarımlarda bulunur.

6. Örnek incelemeler yoluyla kutlama ve törenlerimizdeki uygulamaların kültürümüzü oluşturan unsurlarla ilişkisini değişim ve süreklilik açısından değerlendirir.

7. Orta Asya ilk Türk devletleri ve Türk-i̇slam devletlerinin Türk kültür, sanat ve estetik anlayışına katkılarına kanıtlar gösterir.

\section{Sınıf Kültür ve Miras Öğrenme Alanı Türk Tarihinde Yolculuk Ünitesi Kazanımları}

1. Türkiye Selçukluları döneminde Türklerin siyasal mücadeleleri ve kültürel faaliyetlerinin Anadolu'nun Türkleşme sürecine katkılarını değerlendirir.

2. Şehir incelemesi yoluyla, Türk kültür, sanat ve estetik anlayışındaki değişim ve sürekliliğe ilişkin kanıtlar gösterir.

3. Osmanlı- Avrupa ilişkileri çerçevesinde kültür, sanat ve estetik anlayışındaki etkileşimi fark eder.

4. Seyahatnamelerden hareketle Türk kültürüne ait unsurları örneklendirir4 ${ }^{4}$ (Tablo 2).

\begin{tabular}{|c|c|c|c|}
\hline Üniteler & 6. Sinif & 7. Sinif & $\begin{array}{l}\text { 8. Smuf (İnkulâp Tarihi ve } \\
\text { Atatürkçülük) }\end{array}$ \\
\hline 1 & $\begin{array}{l}\text { Sosyal Bilgiler } \\
\text { Ögreniyorum }\end{array}$ & İletişim ve İnsan Illişkileri & Bir Kahraman Doğuyor \\
\hline 2 & Yeryüzünde Yaşam & Ülkemizde Nüfus & $\begin{array}{l}\text { Milli Uyanış: Yurdumuzun İşgaline } \\
\text { Tepkiler }\end{array}$ \\
\hline 3 & Ipek Yolunda Türkler & Türk Tarihinde Yolculuk & Ya Istiklal Ya Ölüm \\
\hline 4 & Ülkemizin Kaynakları & Zaman İçinde Bilim & Çağdaş Türkiye Yolunda Admmlar \\
\hline 5 & Olkemiz ve Dünya & Ekonomi ve Sosyal Hayat & Atatürkçülük \\
\hline 6 & Demokrasinin Serüveni & Yaşanan Demokrasi & $\begin{array}{l}\text { Atatürk Dönemi Türk Diş Politikası ve } \\
\text { Atatürk'ün Ölümü }\end{array}$ \\
\hline 7 & Elektronik Yüzyıl & Ülkeler Arası Köprüler & $\begin{array}{l}\text { Atatürk'ten Sonra Türkiye: İkinci } \\
\text { Dünya Savaş1 ve Sonrasi }\end{array}$ \\
\hline
\end{tabular}

Tablo 2: Illköğretim Ikinci Kademe Sosyal Bilgiler Dersi Üniteleri

Illköğretim sosyal bilgiler dersi kazanımları göz önünde bulundurulduğunda üzerinde yaşadığımız, geçmiş uygarlıkların bizlere bıraktığı kültürel mirasın korunması gerekliliğini açık bir biçimde ortaya koymaktadır. Bu nedenle Sosyal Bilgiler dersi koruma bilincinin net olarak işleneceği bir derstir.

\section{Din Kültürü ve Ahlak Bilgisi}

Din Kültürü ve Ahlak Bilgisi Öğretim Programı incelendiğinde programın ilkeleri arasında kültürel mirasa saygı açıkça ifade edilerek ‘Kültürel mirasa saygı, tarihi birikime bakabilmek, geçmişe ait bilginin

$4_{\text {www.ttkb.meb.gov.tr }}$ 
günümüz açısından yerini, değerini ve fonksiyonunu tahlil ve tespit edebilmek demektir. Geçmişten devralınan kültürel mirasa kör bir teslimiyet veya onu bilinçsizce tüketmek tarihi mirası anlamada önemli bir engeldir' ifadeleri yer almaktadır 5 . Ancak bu ilke doğrultusunda elde edilmesi hedeflenen kazanımlar sadece 7. sınıf öğrencileri için yazılmıştır.

İlköğretim 7. sınıf Kültürümüz ve Dinimiz ünitesinde yer alan 'Kültürel değerleri korumaya özen gösterir' ve 'Kültürün anlamını ve kültürü oluşturan öğeleri belirtir' kazanımları kültürel mirası koruma bilinci oluşturacak maddelerdirø. Bu kazanımı davranışa dönüştürecek etkinlikler ders kitabında 'Kültür ve Kültürün Öğeleri' konusunda ifade edilmiştir (Demirtaş ve Özdemir, 2011: 124), (Tablo 3).

\begin{tabular}{|l|l|l|l|}
\hline \multicolumn{1}{|c|}{ Üniteler } & \multicolumn{1}{|c|}{ 6. Smuf } & \multicolumn{1}{c|}{ 7. Smuf } & \multicolumn{1}{c|}{ 8. Smuf } \\
\hline $\mathbf{1}$ & $\begin{array}{l}\text { Peygamberlere ve İlahi Kitaplara } \\
\text { Inanç }\end{array}$ & Melek ve Ahiret İnanc1 & Kaza v Kader \\
\hline $\mathbf{2}$ & $\begin{array}{l}\text { Namaz Ibadeti } \\
\mathbf{3}\end{array}$ & Oruç Ibadeti & $\begin{array}{l}\text { Zekât Hac ve Kurban } \\
\text { İbadeti }\end{array}$ \\
\hline $\mathbf{4}$ & Son Peygamber Hz. Muhammed & $\begin{array}{l}\text { Bir Insan ve Peygamber Olarak } \\
\text { Hz. Muhammed }\end{array}$ & $\begin{array}{l}\text { Hz. Muhammed 'in Ömek } \\
\text { Davranış1 }\end{array}$ \\
\hline $\mathbf{5}$ & Kuranı Kerim in Ana Kaynakları & Islam Düşüncesinde Yorumlar & Kuranda Akıl ve Bilgi \\
\hline $\mathbf{6}$ & & Din ve Güzel Ahlak & $\begin{array}{l}\text { İslam Dinine Göre Kótü } \\
\text { Alışkanliklar }\end{array}$ \\
\hline
\end{tabular}

Tablo 3: İlköğretim İkinci Kademe Din Kültürü Dersi Üniteleri

\section{Görsel Sanatlar}

Görsel Sanatlar Dersi Müfredat Programı incelendiğinde, dersin genel amaçları:

Bireysel ve Toplumsal amaçlar arasında,

1. Öğrencinin; ulusal ve evrensel sanat eserlerini ve sanatçıları tanımasını sağlamak,

2. Ulusal ve evrensel değerleri tanıyabilme ve anlayabilme bilincini kazandırmak,

3. Geçmişten günümüze miras kalan sanat eserlerinden haz alma ve onur duyma hassasiyeti kazandırmak, maddeleri;

Estetik Amaçları arasında yer alan;

1. Öğrencinin, sanatın ve sanat eserlerinin her zaman önemsenecek birer değer olduğunu kavramasını sağlamak,

2. Geçmişten günümüze miras kalan sanat eserlerinden ve doğadan haz alma, onlarla gurur duyma ve onları koruma bilincini kazandırmak,

3. Öğrenciye görsel sanatlar sevgisi ve bu sevgiyi hayatının her alanına yansıtabilme, bunu davranış biçimi hâline getirebilme yeterliliği kazandırmak,

\footnotetext{
$5_{\text {www.ttkb.meb.gov.tr }}$

$6_{\text {www.ttkb.meb.gov.tr }}$
} 
4. Öğrenciye, doğadan seçtiği veya insan eli ile üretilen nesneleri estetik birikimini kullanarak değerlendirme bilinci kazandırmak,

5. Öğrenciye kendini ifade edebilmede estetik değerlerden yararlanma yeteneği kazandırmaktır. Maddeleri doğrudan tarihi mekanlara olumlu bakış açısı kazandırmaya ve kültürel mirası koruma bilinci oluşturmaya yöneliktir. Estetik Amaçları arasında yer alan;

1. Öğrencinin, sanatın ve sanat eserlerinin her zaman önemsenecek birer değer olduğunu kavramasını sağlamak

2. Geçmişten günümüze miras kalan sanat eserlerinden ve doğadan haz alma, onlarla gurur duyma ve onları koruma bilincini kazandırmak,

3. Öğrenciye görsel sanatlar sevgisi ve bu sevgiyi hayatının her alanına yansıtabilme, bunu davranış biçimi hâline getirebilme yeterliliği kazandırmak,

4. Öğrenciye, doğadan seçtiği veya insan eli ile üretilen nesneleri estetik birikimini kullanarak değerlendirme bilinci kazandırmak,

5. Öğrenciye kendini ifade edebilmede estetik değerlerden yararlanma yeteneği kazandırmaktır. Maddeleri doğrudan tarihi mekanlara olumlu bakış açısı kazandırmaya ve kültürel mirası koruma bilinci oluşturmaya yöneliktir.

Ayrıca sanatsal ifadelerde görsel ve biçimsel anlatımın yanında, programla ulaşılması beklenen temel beceriler arasında çevre ve doğa bilinci kazanma, millî, manevi ve evrensel değerlere duyarlı olma bilinci yer almaktadır.

Illköğretim Görsel Sanatlar Dersi (1-8. sınıflar) Öğretim Programı ve Kılavuzu üç öğrenme alanı altında yapılandırılmıştır:

1. Görsel Sanatlarda Biçimlendirme

2. Görsel Sanat Kültürü

3. Müze Bilinci

Görsel sanatlar dersinin genel amaçları doğrultusunda kültürel mirası koruma bilinci oluşturabilecek kazanımlar;

\section{Sınıf Görsel Sanatlar Kültürü Alanı}

1. "Sanat eseri" ve "endüstri ürünü" arasındaki farkı söyler.

2. Ulusal kültür mirasımızdan örnekler verir.

3. Ulusların tanınmasında güzel sanatların önemini tartışır.

4. Ulusal kültürü yansıtan ve tanıtan görsel çalışmalar yapar.

5. Gösterilen sanat eserinde anlatılan ve anlatılması mümkün olan fikirler ve duyguları tahmin eder.

6. Gösterilen sanat eserlerinden edindiği izlenimlerden yola çıkarak görsel tasarımlar yapar.

7. Sanattaki niteliği insan eli ve duyarlı̆̆ının belirlediğini fark eder.

8. Doğadaki güzellik ile sanattaki güzelliği karşılaştırır. (Peşkersoy ve Yıldırım 2008: 19). 


\section{Sınıf Müze Bilinci Alanı}

1. Müzedeki eserlerle, bu eserlerin ait oldukları dönemlerdeki sanat anlayışı arasında ilişki kurar.

2. Değişik kültürlere saygı duyar.

3. Eserler aracılığıyla Anadolu uygarlıklarını tanır.

4. Görsel tasarımlarında Anadolu uygarlıklarına ait eserlerden yararlanır.

5. Müzedeki eserlerden yola çıkarak çeşitli görsel tasarımlar yapmanın kendi kültür birikimine katkısını tartışır.

6. Ülkemizin müze, ören yeri, tarihî eser, anıt vb. zenginliklere sahip olmasından gurur duyar (Peşkersoy ve Yıldırım, 2008: 20).

\section{Sınıf Görsel Sanatlar Kültürü Alanı}

1. Doğanın, sanat eserinin oluşumundaki rolünü örnekler vererek açıklar.

2. Duyguların sanatsal yaratıcılığa katkısını fark eder.

3. Sanat eserlerindeki soyut ve somut ifade biçimlerini ayırt eder.

4. Grafik tasarım ürünlerinde sembol, işaret, renk ve lekelerin işlevlerini ayırt eder.

5. Piktogramların evrensel görsel semboller olarak günlük yaşamdaki önemini kavrar.

6. Gösterilen eserin konusunu göz önünde bulundurarak sanatçının çevresinden nasıl etkilendiğini tartışır.

7. Sanat eserinin toplumla sanatçısı arasında bir iletişim aracı olduğunu fark eder.

8. İlgi duyduğu sanat eserleri ve sanatçılar hakkında araştırma yapar.

9.Güzellik kavramının ölçütlerinin kültürlere göre farklılaşabileceğini değer sistemine katar.

10. Yaşadığı çevrenin yöresel özelliklerinden esinlenerek görsel tasarımlar yapar (Peşkersoy ve Yıldırım 2008: 139)

\section{Sınıf Müze Bilinci Alanı}

1. Müzelerin, ulusal ve evrensel kültür ürünlerinin geçmişten geleceğe taşındığı mekânlar olduğunu kavrar.

2. Ulusal kültürümüze sahip çıkmanın önemini kabul eder.

3. Tarihî eserlerin ve kültürün taşıyıcısı niteliğindeki sanat eserlerinin kayıt altına alınmasının gerekliliğini ve önemini fark eder.

4. Sanat eserinin özelliklerini kavrar.

5. Tarihî eserlerin özelliklerini açıklar.

6. Tarihî eser ile sanat eserinin özellikleri arasındaki farkı belirler.

7. İlgi duyduğu sanat eserleri hakkında araştırma yapar.

8. Tarihî eserlerimize sahip çıkılmasının herkes için bir ulusal görev 
olduğunu benimser.

9. Kültürel miras olan eserlerin, kaçakçılığının sonuçlarını tartışır.

10. Ülkemizin müze, ören yeri, tarihî eser, anıt vb. zenginliklere sahip olmasından gurur duyar.

11.Tarihî eserlerin müzelere teslim edilmesi gerektiğinin bilincine ulaşır (Peşkersoy ve Yıldırım 2008: 140).

\section{Sınıf Görsel Sanat Kültürü Alanı}

1. Sanatın kendine özgü evrensel bir dili olduğunu kabul eder.

2. Farklı sanat akımları hakkında bilgi edinir.

3. Farklı ifade biçimlerinin sanatın dallarını oluşturduğunu fark eder.

4. Duygu ve düşüncelerini görsel sanatların farklı dalları ile ifade edebileceğini bilir.

5. Karşılaştığı evrensel ve ulusal sanat eserlerinin sanatçılarının yaşam öykülerini öğrenmeye istek duyar.

6. Gösterilen sanat eserindeki görsel biçimlendirme öğelerinin sanatsal düzenleme ilkelerine göre nasıl düzenlendiğini açılar.

7. Sanat eserlerindeki konu çeşitliliğini sorgular.

8. Görsel sanat eserinin oluşmasında, dönemin düşünce ve inanç sistemlerinin, coğrafi özelliklerinin ve çeşitli olayların etkisini tartışır.

9. Sanatın kültürü aktarma yollarından biri olduğuna ilişkin örnekler verir.

10. Teknolojik gelişmelerin görsel sanatlara etkisini açılar.

11. Duygularını, düşüncelerini ve izlenimlerini yansıtan görsel tasarımlar yapar.

12. Gördüğü sanat eseri hakkında estetik bir yargıya varır (Peşkersoy ve Yıldırım, 2008: 156).

\section{Sınıf Müze Bilinci Öğrenme Alanı}

1. Türk müzeciliğinin kurulmasında öncülük eden kişileri araştırarak bilgi edinir.

2. Seçtiği herhangi bir eserin müzeye ulaşma sürecini araştırır.

3. Internet üzerinden bir müze ziyareti yapar.

4. Internet üzerinden araştırdığı müzeye yönelik tanıtıcı görsel çalışmalar yapar.

5. Kültürel mirasa sahip çıkmanın önemini pekiştirmede bilişim teknolojilerinden yararlanır.

6. Müzedeki eserler, tarihî yapılar, anıtlar vb. den yola çıkarak görsel tasarımlar yapar.

7. Ülkemizin müze, ören yeri, tarihî eser, anıt vb. zenginliklere sahip olmasından gurur duyar.

8. Tarih, kültür ve görsel sanatlar arasındaki ilişkinin farkına varır (Peşkersoy ve Yıldırım, 2008: 157). 
Görüldüğü üzere Görsel Sanatlar dersi öğrencilerde koruma bilinci oluşturacak en kapsamlı kazanımlara sahiptir. Dolayısıyla koruma bilinci, net olarak bu dersin konusudur ve açıkça tarihi eserlerin korunma ve bakımının önemini vurgulamaktadır.

Etkili öğrenmenin, iyi bir iletişimle gerçekleştiği tezinden hareket ederek diyebiliriz ki, her müze etkili öğretimi gerçekleştirmek için, iyi bir iletişim politikası hazırlamalı, eğitim faaliyetlerini buna göre yapmalıdır. Bunu yapabilmede en önemli unsur, koleksiyonları ve objeleri gereğine uygun şekilde sergileme biçimidir. Bu bakımdan sergilemeyi, müzenin zenginliklerini dışa yansıtması olarak kabul edebiliriz (Zor, 2007: 62).

\section{Sanat Etkinlikleri}

Illköğretim ikinci kademede okutulan ve kültürel miras kavramı ile doğrudan bağlantılı bir ders de seçmeli olarak okutulan Sanat Etkinlikleri dersidir. Bu dersin genel amaçları incelendiğinde 'Öğrencilerin bilgi, beceri ve değerlerini geliştirmelerine, sosyal, kültürel, eğitsel, bilimsel, sportif ve sanatsal etkinliklerle kültürü özümsemelerine yardımcı olmak' maddesi ile karşılaşılmaktadır (MEB, 2006a: 16).

Bu ders, başta tiyatro ve drama olmak üzere müzik, resim, heykel, mimari, dans, edebiyat alanlarından yararlanarak öğrencilerde sanata, kültüre ve kültürel değerlere olumlu bakış açııı kazandırabilecek önemli bir derstir.

Sanat etkinlikleri dersi Sanatlar Eğitimi, Müze Kültürü ve Proje Çalışmaları öğrenme alanları dâhilinde oluşturulmuş kazanımlardan oluşur. Ancak bu kazanımlardan sadece 7. sınıf müze kültürü öğrenme alanında yer alan 'Müzedeki uygarlıklar hakkında bilgi sahibi olur' ve 'Müzedeki eserleri ve kahramanları farklı sanatsal yollarla ifade eder' maddeleri doğrudan kültürel miras bilinci oluşturmaya yöneliktir.

\section{Halk Kültürü}

İlköğretim ikinci kademede seçmeli olarak okutulan Halk Kültürü Dersinin genel amaçları arasında kültürel mirası koruma bilinci oluşturabilecek 'küreselleşme sürecinde Türk halk kültürünü ve millî bilincin oluşmasını sağlayan kültürel mirasın korunması, yaşatılması ve geliştirilmesi gerekliliğini fark eder' maddesi yer almaktadır.

$\mathrm{Bu}$ genel amaç doğrultusunda doğrudan koruma bilinci oluşturabilecek maddeler;

\section{Sınıf Küreselleşme ve Hak Kültürü Öğrenme Alanı Kültürel Mirası} Koruma Bilinci Ünitesi Kazanımları:

1. Somut Olmayan Kültürel Miras Sözleşmesi'ni tanır.

2. Yerel, kültürel zenginliklerin küreselleşme sürecindeki yerini fark eder. 
3.Kültürel mirası benimseme ve koruma konusunda duyarlı olur (Özpolat ve diğerleri, 2007: 41).

\section{Sınıf Halk Sanatları Öğrenme Alanı Geleneksel El Sanatları Ünitesi Kazanımları}

1. Kültür turizminde yararlanılan halk kültürü ürünlerini araştııır.

2. Günümüzde el sanatlarına yeniden duyulan ilginin nedenlerini sorgular.

3. El sanatlarının halkın ihtiyaçlarından doğduğunu, halkın zevk ve yaratıclığını yansıttığını fark eder.

4. Halk kültürünün geçmişteki durumunun öğrenilmesinde ve geleceğe aktarımasında yazılı kaynakların yerini ve önemini fark eder (Özpolat ve diğerleri, 2007: 46).

\section{Sınıf Küreselleşme ve Halk Kültürü Öğrenme Alanı Müze ve Halk} Bilim Müzeciliği Ünitesi

1. Halk mimarisini koruma ve yaşatma yöntemlerine ilişkin önerilerde bulunur.

\section{Sınıf Halk Sanatları Öğrenme Alanı Halk Mimarisi Ünitesi Kazanımları}

1. Halk kültürü ile ilgili müzelerden dönemin halk yaşamı konusunda bilgi edinir.

2. Kültürel öğelerin toplanması, korunması ve müzeleştirilmesinin önemini kavrar.

3. Müzenin kuşaklar arası kültürel iletişimin oluşmasına katkı sağladığının farkına varır (Özpolat ve diğerleri, 2008: 59), (Tablo 4).

\begin{tabular}{|c|c|c|c|c|}
\hline Dersler & Smif & Kazanım Sayısı & $\begin{array}{l}\text { Korumaya Yönelik } \\
\text { Kazanmm Sayısı }\end{array}$ & Etki \\
\hline \multirow{3}{*}{ Türkçe } & 6 & 197 & - & - \\
\hline & 7 & 201 & - & - \\
\hline & 8 & 198 & - & - \\
\hline \multirow{3}{*}{ Sosyal Bilgiler } & 6 & 43 & 7 & $\% 16.2$ \\
\hline & 7 & 39 & 4 & $\% 10.2$ \\
\hline & - & - & - & - \\
\hline \multirow{3}{*}{ Görsel Sanatlar } & 6 & 23 & 10 & $\% 43.5$ \\
\hline & 7 & 30 & 12 & $\% 40$ \\
\hline & 8 & 27 & 10 & $\% 37$ \\
\hline \multirow{3}{*}{ Din Kültürü } & 6 & 47 & - & - \\
\hline & 7 & 50 & 2 & $\% 1$ \\
\hline & 8 & 44 & - & - \\
\hline \multirow{3}{*}{ Sanat Etkinlikleri } & 6 & 17 & - & - \\
\hline & 7 & 27 & 2 & $\% 7.5$ \\
\hline & 8 & 15 & - & - \\
\hline \multirow{3}{*}{ Halk Kültürü } & 6 & 26 & 3 & $\% 11.5$ \\
\hline & 7 & 33 & 4 & $\% 12$ \\
\hline & 8 & 31 & 3 & $\% 9.6$ \\
\hline
\end{tabular}

Tablo 4: Kazanımlar Tablosu 
Tablo 4'te oluşturulan kazanımlar tablosu incelenen derslerden elde edilen verilerden oluşmaktadır. Tabloda ders kazanımları göz önünde bulundurulduğunda hangi dersin kazanımlarının yüzde kaçının kültürel mirasımıza karşı olumlu bakış açısı kazandırabileceğini göstermektedir. Tablo 4 incelendiğinde Görsel Sanatlar dersinin kültür varlıklarını korumada en etkili ders olduğu, Sosyal Bilgiler, Sanat Etkinlikleri, Halk Kültürü ve Din Kültürü ve Ahlak Bilgisi derslerinin de kültür varlıklarını koruma bilinci oluşturmada önemli katkılarının olduğu görülmektedir. En fazla kazanıma sahip olan Türkçe dersinin ise koruma bilinci oluşturacak herhangi bir kazanımın olmadığı görülmektedir.

\section{Sonuçlar}

İlköğretim ikinci kademede okutulan derslerden, doğrudan veya dolaylı, kültürel mirası koruma bilinci oluşturmaya yönelik dersler Türkçe, Sosyal Bilgiler, Din Kültürü ve Ahlak Bilgisi, Görsel Sanatlar, Sanat Etkinlikleri ve Halk Kültürü dersleridir. Bu dersler ülkemizin kültürel değerlerinin evrensel kültür çeşitliliğinin önemli bir parçası olduğunu ve bu değerlerin korunması gerektiğini vurgulamaktadır.

Incelenen müfredat programları genel amaçları ve ilkeleri arasında milli kültürün önemine değinmiştir. Türkçe dersi içeriği itibariyle kültürel kimliğin önemli bir parçası olmalıdır. Ancak bu dersin kazanımları arasında bu genel amaca hizmet eden herhangi bir kazanım yer almamaktadır. Öte yandan Görsel Sanatlar dersinin ders süresinin haftada bir saat olmasına rağmen kazanımlarının yüzde kırkının doğrudan kültürel miras bilinci oluşturmaya yönelik olması dikkat çekici bir sonuç olarak ortaya çıkmışır.

Görsel Sanatlar, Sosyal Bilgiler ve Halk Kültürü dersleri doğrudan kültürel mirası koruma bilinci oluşturmaya yönelik kazanımlar içermektedir. Türkçe, Din Kültürü ve Ahlak Bilgisi, Sanat Etkinlikleri dersleri ise ünitelerinde yer alan konular ve okuma parçaları ile dolaylı olarak koruma bilinci oluşturmaya yöneliktir.

Ders kitapları içerdiği metin, resim ve grafikler ile öğrencileri görsel açıdan destekleyen önemli materyallerdir. Koruma bilinci oluşturmada çok önemli bir paya sahip olan görsel sanatlar dersinin ders kitabı olmaması bu yönde önemli bir eksiklik olarak karşımıza çıkmaktadır.

Kültür ve doğa varlıklarının öğrenilmesi ve nasıl korunacağının bilinmesi bir gerekliliktir. Bu sebeple koruma bilinci oluşturmaya yönelik kazanımların başta Türkçe dersi olmak üzere sanat etkinlikleri ve din kültürü derslerinde arttırılması gerekmektedir.

Koruma ile ilgili kazanımların bulunmadığı derslerde dolaylı olarak bu bilinci verecek konuların, okuma parçalarının ders kitaplarında yer alması gerekmektedir. Ayrıca Teknoloji ve Tasarım dersinde, Düzen, Kurgu ve Yapım kuşaklarına 'onarım' konusu eklenebilir. 
Bu araştırma, koruma bilinci oluşturmada en etkili dersin görsel sanatlar dersi olduğunu ortaya koymaktadır.

Araştırma inceleme, tartışmalar, eğitsel oyunlar, dramalar, ders dışı gezilerden oluşan çağdaş öğretim yöntemleri ile kültür varlıklarının tanınması ve değerlere karşı olumlu bakış açısının geliştirilmesi daha etkili olacaktır. Bu etkinliklerin arttırılması ve desteklenmesi gerekmektedir. 


\section{Kaynakça}

Altınörs, A. (2010). Korumanın Toplumsal ve Kültürel Boyutu Neden Önemli? Biz Nasıl Bakıyoruz?, Planlama, 2010(1), 29-37.

Asatekin, N.Gül. (2004). Kültür ve Doğa Varlıklarımız Neyi Niçin Nasıl Korumalıyız. Ankara: DOSiM Basımevi.

Asatekin N.Gül. (2005). 'illköğretim II. Kademe Öğrencilerinde Restorasyon/Koruma Bilincinin Niteliğinin Saptanması Konusunda Ders Kitabının Rolü', 60. Yaşında Sinan Genim'e Armağan Makaleler.

Bilgili, Ahmet Emre. (2010). Şehir ve Kültür, Eşsizliğin Doruk Noktası: İstanbul, Şehir ve Kültür: İstanbul, İstanbul: Ebru Matbaacılık.

Çubuk, M. (1998). Çağdaş Kentsel Kültür Mirası Kentsel Korumayenileme Kentsel İyileştirme, İstanbul: MSÜ Matbaası.

Demirtaş, K. \& Özdemir, M. (2011). Din Kültürü ve Ahlak Bilgisi 7. Sınıf, Ankara: MEB Yayınları.

Göğebakan, Y. (2009). "Görsel Sanatlar ve Sosyal Bilgiler Derslerinin İlişkilendirilmesinin Kültür Varlıklarını Tanıma ve Sahip Çıkma ile İlgili Kazanımların Gerçekleşmesi ve Öğrencilerin Tutumları Üzerine Etkisi" Yayımlanmamış Doktora Tezi Gazi Üniversitesi Eğitim Bilimleri Enstitüsü Güzel Sanatlar Eğitimi Bölümü Resim İş Öğretmenliği Bilim Dalı, Ankara.

Hueber F. (1991). Arkeolojik Yapıların ve alanların Koruma Restorasyon Sorunları' Arkeolojik Sit Alanların Korunması ve Değerlendirilmesi I. Uluslararası Sempozyumu, 14-16 Ekim Antalya.

MEB (2006a). Illköğretim Sanat Etkinlikleri Dersi Programı ve Kılavuzu 1-8. Sınıflar, Ankara: MEB Yayınları.

MEB (2006b). Illköğretim Türkçe Dersi 6,7,8. Sınıflar Öğretim Programı, Ankara: MEB Yayınları.

Özden, E. Ö. (Ağustos 2005). “Planlama-Koruma Üzerine Çözüm Arayışları Marmara Takımadaları, Beykoz, Tarihi Yarımada Sit Alanlarına iliş̧kin Çözümleme", Planlama Dergisi, (32), 23-35.

Özpolat, V. Uysal, S. Demir, R. Dombaycı, R. Sütçü, M.A. (2007). İlköğretim Halk Kültürü (7. Sınıf) Dersi Öğretim Programı ve Kılavuzu, Talim ve Terbiye Kurulu Başkanlığı, Ankara.

Özpolat, V. Uysal, S. Demir, R. Dombaycı, R. Sütçü, M.A. (2008). İlköğretim Halk Kültürü (8. Sınıf) Dersi Öğretim Programı ve Kılavuzu, Talim ve Terbiye Kurulu Başkanlığı, Ankara. 
Peşkersoy, E. \& Yıldırım, O. (2008). Ilköğretim Görsel Sanatlar Dersi 1-8. Sınıflar Öğretmen Kılavuz Kitabı, İstanbul: Kelebek Matbaacılık.

Tankut, G. (1991). Kentsel Arkeolojik Alanlarda Arkeolojik Değerlerin Kent Hayatına Katılımı, Korumanın Fiziksel planlama Boyutu, Arkeolojik Sit Alanların Korunması ve Değerlendirilmesi I. Uluslararası Sempozyumu, Antalya.

Yılmaz, G. \& Üçer Z. A. G. (2004). Türkiye'de Kentsel Koruma Sürecinde Sivil Toplum Kuruluşları Üzerine Bir Değerlendirme, Ege mimarlık, İzmir.

Tapan, M. (17 Haziran 2010). Kültür Varlıklarımızı Neden Koruyamıyoruz, Cumhuriyet Gazetesi, 5.

Zor, A. (2007). Müzelerin Konuşma Arzusu, ICANAS 38, Uluslararası Asya ve Kuzey Afrika Çalışmaları Kongresi, Atatürk Kültür, Dil ve Tarih Yüksek Kurumu Yayınları, Ankara.

\section{Internet Kaynakları:}

Internet: MEB Talim ve Terbiye Kurulu Başkanlığı ttkb.meb.gov.tr (2007).

Web: http://ogm.meb.gov.tr/belgeler/tarih9.pdf adresinden 15 Ağustos 2011'de alınmıştır.

Internet: MEB Mevzuat mevzuat.meb.gov.tr (Kasım 1985).

Web:http://mevzuat.meb.gov.tr/html/kanun2709-1.htm adresinden 15 Ağustos 2011'de alınmıştır. 